\title{
TECHNOLOGY ACCEPTANCE AS A DETERMINANT OF ONLINE GROCERY SHOPPING ADOPTION
}

\author{
Radka Bauerová ${ }^{1}$, Martin Klepek ${ }^{1}$ \\ ${ }^{1}$ Department of Business Economics and Management, Faculty of Business Administration, Silesian University in \\ Karviná, Univerzitní náměstní 1934/3, 73340 Karviná, Czech Republic
}

\begin{abstract}
BAUEROVÁ RADKA, KLEPEK MARTIN. 2018. Technology Acceptance as a Determinant of Online Grocery Shopping Adoption. Acta Universitatis Agriculturae et Silviculturae Mendelianae Brunensis, 66(3): 737-746.

Online grocery shopping plays an important role in the current online market as the most evolving online shopping category. Despite that, consumers adopt this way of shopping quite differently across European countries. To explain such a difference, the Technology acceptance model (TAM) can be used for better understanding consumer behaviour toward habitual online shopping. This paper goes beyond and applies TAM in online grocery area based on the assumption that customers view online grocery shopping as an interaction with system respectively web page interface. The aim of the paper is to explain consumer behaviour in the domain of online grocery shopping. Structural equation modelling was chosen to determine factors influencing online grocery shopping and moreover, to find positive relationships between them. The online quantitative questionnaire was given to 480 respondents. Analysis showed a positive relationship between Perceived Usefulness (PU), Perceived Ease of Use (PEOU) and Behavioural Intention (BI). The final scheme has characteristics of simple path model with a sequence of latent constructs where PEOU has a positive effect on PU and PU consequently effects BI. Perceived Usefulness of online grocery shopping have a direct effect on Intention to buy, therefore plays a crucial role in awakening the interest in buying food online.
\end{abstract}

Keywords: online grocery shopping, technology acceptance model, consumer's behaviour, structural equation modelling, consumer's technology acceptance

\section{INTRODUCTION}

Internet and new technologies are massively expanding and have changed consumers in their everyday lives. Shopping on the internet is a phenomenon for customers. The fact that internet and technology redefined the process of acquiring goods and services has contributed to the popularity of online shopping. In 2016, global e-retail sales reached 1.9 trillion U.S. dollars, but projections show up to 4.06 trillion U.S. dollars by 2020 (Statista, 2017). Nearly 67\% of EU internet users shopped online in 2013 (Eurostat, 2017). In the Czech Republic, for example, $13 \%$ of individuals purchased goods online in 2003, while, in 2016, the number of individuals purchasing goods online was $47 \%$ (CSO, 2017). This development of e-commerce shows that customers have quickly utilized this unconventional, but convenient way of shopping around the world.

Depending on the development of internet grocery purchases by individuals, the most evolving category of online shopping is online grocery shopping (OGS) (Eurostat, 2017; Statista, 2017). The Nielsen company found (60 countries examined) that one-quarter of respondents say they order online grocery products online, and more than half $(55 \%)$ are willing to do it in the future (The New Retail Report, 2015). The highest shares of online grocery shoppers were registered in the United Kingdom (35\%), Netherlands (28\%), Slovenia (28\%), Estonia (27\%), Germany (26\%) and Lithuania (26\%), whereas only $10 \%$ of individuals shopped grocery online in the Czech Republic (Eurostat, 2017). The question is what causes the significant 
difference in consumer's behaviour toward online grocery shopping.

OGS is at the forefront of companies and researchers interest now (Monsuwé et al., 2004; Kurnia and Chien, 2003; Munson et al., 2017; The New Retail Report, 2015). Understanding consumers' motivations and limitations to shop online are of a major importance for companies. Monsuwé et al. (2004) highlight four main areas for which the understanding is crucial. These are strategic, technological, marketing decisions as well as website design. In the following paragraphs, we will analyse these areas and choose the one that is decisive for this research.

OGS is a time-consuming activity for companies due to service issues (perishability of grocery items and complexity of service offering) and managerial issues (planning and commitment from management) (Weber and Badenhorst-Weiss, 2016). Therefore, Weber and Badenhorst-Weiss (2016) argue that the time-based competition (TBC) strategy could be a feasible competitive strategy for online grocery retailers to gain a competitive advantage. The purpose of TBC strategy is to achieve a significant competitive advantage through the effective utilisation of time (Stalk, 1988). TBC deals with external time performances (improved delivery time and/or higher frequency of introducing new products to the market or improving the existing ones) as a source of competitive advantages (Toni and Meneghetti, 2000).

In the technological area a successful implementing of technology support online grocery shopping is important On the company side, lack of operational efficiency and poor logistics consequent to an inappropriate control on the physical and information flows makes e-grocery unsuccessful on the market (Cagliano et al. 2017). On the customer side, it is important to set up the technology and website design to suit the customer's needs and wishes. Website design quality, especially ease of navigation, access, loading time, content usefulness and attractiveness, has a high impact on customer's behaviour (Al-Qeisi et al., 2014).

This paper focuses on the website design area to find optimal the webpage's user interface. The research also provides information useful in marketing decisions when targeting marketing tools to individual segments of customers.

The OGS service is offered by both companies that trade only online (e-tail) as well as traditional store companies (hybrid companies). In the case of hybrid companies, it is important to effectively manage all sales channels (e.g. website, traditionally store, call centre) to make consumers satisfied. Especially the generation $\mathrm{Y}$ consumers prefer an online source of information before traditional media (Klapilová-Krbová, 2016). Therefore multichannel customer management is an emerging strategic area of decision-making for marketers of hybrid companies in these days. Effective design, deployment, and evaluation of channels to enhance customer value through effective customer acquisition and development are perceived as key marketing decisions (Neslin et al., 2006).

Researchers are particularly interested in the behaviour of customers purchasing grocery online. For instance, the online brand selection is almost identical to usual customer's behaviour in traditional store (Anesbury et al., 2016). However online grocery websites usually sell local fresh and tasty food, which positively affects customers who want to support their local production and community (Miškolci, 2017). Differences in buying behaviour between online and traditional purchasing environments are obviously caused by the interface and the possibilities of online technology. For example, the web interface decreased significantly the shopping time needed to buy grocery (Anesbury et al., 2016). Consumer's behaviour has gradually changed in basket composition by product category with the continuous development of online grocery shopping in response to the unique opportunities and challenges of OGS. For example, online consumer's spend more on fresh products than offline, contrary to popular prejudice that customers are afraid of shop fresh products online (Munson et al., 2017).

Today's retailing customers are faced with new technologies such as self-checkout service (Orel and Kara, 2014), portable touch scanners (Nathalie and Djelassi, 2016) or electronic shelf labels (Soutjis et al., 2017). Furthermore, there are innovations associated with e-commerce environments (Reinartz et al., 2011).

Technology and its broad acceptance play important role in retail as well as in the e-tail shopping. Its acceptance can be defined as behaviour that enables or promotes (support) the use of a technology, rather than inhibits or demotes (resistance) the use of it (Huijts et al., 2012).

Technology acceptance of customers is influenced by different factors. These can be investigated through the Technology Acceptance Model (TAM). Commonly used to measure effects of system characteristics on information system acceptance (Davis, 1989).

The aim of the paper is to explain consumer behaviour in the domain of online grocery shopping. To do that, the TAM framework is implemented on online grocery shopping intentions using structural equation modelling approach to theory testing.

This paper discusses the technology acceptance of the customers buying grocery online. Through the technology acceptance model, it examines customer's perceptions, attitudes and intentions. Specifically, the target population are online customers who already bought grocery online. We will describe and explore factors that have a direct or indirect influence on customers' intention to buy grocery online.

This paper is structured as follows. First, we discuss in literature review the theoretical assumptions of OGS and further the TAM framework and its components. Second, we present 
our methodological choices, mainly the structural equation model (SEM) development, data collection and analysis. Third, the results of our study are presented and in the final part of the paper, we discuss the core findings and present a conclusion.

\section{Online Grocery Shopping Models}

In the past, models reflecting the acceptance of online grocery shopping have been developed, but these models have not been investigated using Confirmatory Factor Analysis (CFA). Researchers could not evaluate the contribution of each scale item as well as incorporate how well the scale measures the concept because CFA was not used (Hair et al., 2010). Therefore, in the following models, researchers did not know how well the model fits the data. However, these models are listed here as they are based on TAM assumptions and work with PU, PEOU, BI and other variable factors. Into models reflecting OGS (not tested by CFA), we can include the following:

The first OGS model is an Acceptance Model of Online Grocery Shopping designed by Kurnia and Chien (2003). This model demonstrated using Pearson's correlation, multiple regression and Pointed-Biserial Correlation, the applicability of the TAM in assessing the acceptance of OGS. In this model was confirmed that the PU of OGS was influenced directly by its PEOU (Kurnia and Chien, 2003). When examining proposed variables (visibility, social influence and perceived risk) for the OGS model, was found that only the visibility factor has a positive impact on the attitude towards using OGS. Factor visibility implies that the more often potential adopters observe OGS used by others, the more likely they are to establish a positive attitude towards using it (Kurnia and Chien, 2003).

The second OGS model is an E-Grocery Acceptance Model designed by Wolf (2012). The mediator analysis was used to investigate the proposed model. In this model, the PU factor has not been examined at all, which has been confirmed by many researchers as a stronger BI predictor than PEOU, as mentioned above. Since this model is designed on the base of original TAM model, we perceive the missing PU factor as the model deficiency, which could distort the result of the investigation. The model is designed to repeat OGS and therefore we think that choosing PEOU as a more important factor than PU is inadequate due to the continuous increase in the ability to use the system by repeated purchase by an e-customer. The model proposed Perceived Time Pressure, Perceived Convenience, Perceived Offline Enjoyment, Perceived Risk, Positive Past Experience and Situational Factors as several factors that could be identified leading to a positive attitude towards OGS (Wolf, 2012).

\section{Theoretical base of the Technology Acceptance Model}

TAM, designed by Davis (1987), provides a foundation for research on why users accept or reject information technology and how to improve user acceptance by judicious choice of system design features. The model has gradually evolved over the years. Many modifications were proposed and tested empirically such as TAM2, TAM3 or extended TAM for e-shopping. To shortly map the development, TAM2 identified general determinants of PU (Venkatesh and Davis, 2000). In addition, TAM3 combined TAM2 and the model of the determinants of PEOU, resulting in an integrated model of technology acceptance (Venkatesh and Bala, 2008).

The extended TAM for e-shopping examines the influence of PU, PEOU, attitude and variables factors on e-customer's behaviour. The model shows attitude as the strong direct predictor of e-shopping acceptance, moreover, TAM with attitude explains an additional $9 \%$ of the variance in e-shopping intention (Ingham et al., 2015). The attitude is an individual's disposition to respond favourably or unfavourably to an object, person, institution, or event or to any other discriminable aspect of the individual's world (Ajzen, 1989). In TAM based studies, PEOU and PU typically have a positive significant effect on attitude (Lim and Ting, 2014; Monsuwé et al., 2004; Ingham et al., 2015).

\section{Perceived Usefulness and Perceived Ease of Use}

Davis named two determinants based on his previous research as perceived usefulness and perceived ease of use, that are important for understanding what causes people to accept or reject information technology (Davis, 1987).

Perceived usefulness (PU) in the original TAM was defined as the degree to which a person believes that using a particular system would enhance his or her job performance (Davis, 1989). Within an online grocery shopping context, we can analogically assume that the individual behavioural intention of online grocery buyers believe that the use of the system is useful in their personal life.

Davis (1989) defined perceived ease of use (PEOU) in the original TAM as the degree to which a person believes that using a particular system would be free of effort. Within an online grocery shopping context, we can analogically assume that the individual behavioural intention of customers buying grocery online explains the confidence that using websites to order food online is easy.

Davis stated that PEOU has a causal effect on PU, which is confirmed by several studies (Davis, 1987; Venkatesh and Davis, 2000; Gefen et al., 2003; Rauniar et al., 2014). PEOU can have a significant direct effect on PU because, between two systems that perform the identical set of functions, a user should find the one that is easier to use more useful (Davis, 1987).

In 1989, Davis developed and validated new measurement scales for perceived usefulness and perceived ease of use, two distinct variables as determinants of computer usage. He found 
out that usefulness was linked significantly more to usage than the ease of use was. Thus, users are driven to adopt an application primarily because of the functions it performs for them, and secondarily for how easy or hard it is to get the system to perform those functions (Davis, 1989). The stronger relationship between perceived usefulness and behavioural intention (BI), unlike from BI and perceived ease of use, was confirmed also by other researchers (Venkatesh and Bala, 2008; Ingham et al., 2015).

As was mentioned above, this paper applies Technology Acceptance Model in order to determine the antecedents of consumer's behaviour in online grocery shopping (OGS). The TAM application for OGS is in Fig. 1. Following hypotheses were formulated based on the literature review:

$\mathrm{Hl}$ : Perceived Usefulness has a positive effect on Behavioural Intention toward buying grocery online.

H2: Perceived Ease of Use has a positive effect on Behavioural Intention toward buying

grocery online.

H3: Perceived Ease of Use has a positive effect on Perceived Usefulness.
H4: Perceived Usefulness has a positive effect on Attitude towards buying grocery online.

H5: Perceived Ease of Use has a positive effect on Attitude towards buying grocery online.

H6: Attitude towards buying grocery online has a positive effect on Behavioural Intention toward buying grocery online.

\section{MATERIALS AND METHODS}

To meet the research objectives, we had to make several methodological choices. First was to adopt positivistic research philosophy since we were aiming to use mainly deductive approach and test previous theories and empirically tested models of technology acceptance. Positivism is a research philosophy which uses existing theory to develop hypotheses and then collect data for analysis (Saunders et al. 2016). The second choice was to use survey data collection strategy and cross-sectional time horizons for our research. That is to say, we adopted online questionnaire and collected data in a single period of time. Specifically, in October 2017.

To test hypothesized model, Likert scales were used to measure theoretical constructs. It is a widely

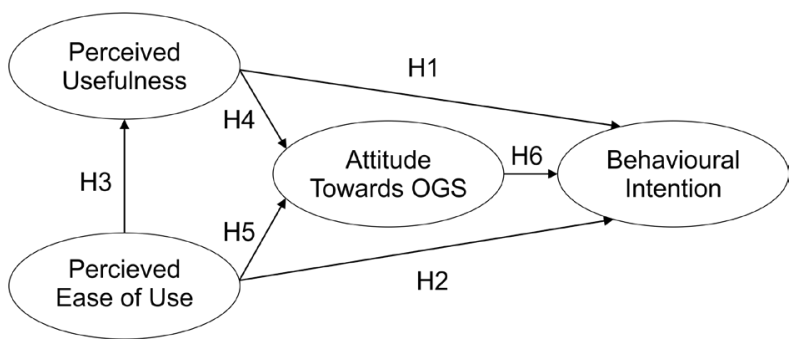

1: Structural model

Source: own elaboration based on Davis (1989)

I: Items used

\begin{tabular}{|c|c|c|c|}
\hline Construct & Question & Code & Source \\
\hline \multirow{3}{*}{$\begin{array}{l}\text { Perceived } \\
\text { Usefulness (PU) }\end{array}$} & Online grocery shopping enables me to save my time. & PUl & Davis (1987) \\
\hline & $\begin{array}{c}\text { Using the website for grocery shopping makes it easier to do my } \\
\text { shopping. }\end{array}$ & PU2 & Davis (1987) \\
\hline & Overall, I find the website for grocery shopping useful in my life. & PU3 & Davis (1987) \\
\hline \multirow{3}{*}{$\begin{array}{l}\text { Perceived Ease } \\
\text { of Use (PEOU) }\end{array}$} & $\begin{array}{c}\text { Learning to use online grocery shopping through the website was easy } \\
\text { to me. }\end{array}$ & PEOU1 & $\begin{array}{l}\text { Celik and Yilmaz } \\
\text { (2011) }\end{array}$ \\
\hline & $\begin{array}{c}\text { It is easy for me to remember how to perform tasks needed for grocery } \\
\text { shopping using the website. }\end{array}$ & PEOU2 & Davis (1987) \\
\hline & Overall, I find grocery shopping through the website easy to use. & PEOU3 & Davis (1987) \\
\hline \multirow{3}{*}{$\begin{array}{l}\text { Attitude } \\
\text { towards } \\
\text { online grocery } \\
\text { shopping (ATT) }\end{array}$} & Grocery shopping through the website is attractive to me in my daily life. & ATT1 & Hansen et al. (2004) \\
\hline & Grocery shopping through the website is pleasant & ATT2 & Childers et al. (2001) \\
\hline & Using the website for grocery shopping is good idea. & ATT3 & Childers et al. (2001) \\
\hline \multirow{3}{*}{$\begin{array}{l}\text { Behavioural } \\
\text { Intention to } \\
\text { online grocery } \\
\text { shopping } \\
\text { (BI) }\end{array}$} & $\begin{array}{l}\text { Given that I have access to the internet, I predict that I would use it for } \\
\text { grocery shopping. }\end{array}$ & $\mathrm{B} 11$ & $\begin{array}{l}\text { Venkatesh and } \\
\text { Davis (2000) }\end{array}$ \\
\hline & I intend to use website for grocery shopping as soon as possible. & B12 & $\begin{array}{l}\text { celik and Yilmaz } \\
\text { (2011) }\end{array}$ \\
\hline & I will regularly use online grocery shopping in the future. & B13 & $\begin{array}{l}\text { celik and Yilmaz } \\
\text { (2011) }\end{array}$ \\
\hline
\end{tabular}


used rating scale that requires the respondent to indicate a degree of agreement or disagreement with each of series of statements (Malhotra and Birks, 2012). In this case, the seven-point scale was used to allow respondents to specify the level of agreement with statements extracted from literature review (Tab. I).

Questions were presented in randomized order so the respondents were not aware of the structure of measured constructs.

\section{Data collection and examination}

Data were collected in cooperation with IPSOS research agency through its online respondent panel. The panel is certified by SIMAR authority and has several control mechanisms to ensure data quality. There is a respondent's duplicity control, limits for the maximal participation of each respondent in studies, respond time check or identity and personal data validation.

Despite the mentioned mechanisms for quality control, we examined final data set for few standard problems. Hair et al. (2017) recommend paying attention to missing data, outliers, data distribution and suspicious response patterns.

A quick analysis of blank cells in Microsoft Excel showed complete data from all 1050 respondents. Further, outliers were analysed only in case of age since the rest of the questions had nominal or ordinal nature. SPSS box plot with a respondent number as a label for cases did not show any outlier. Graphical methods were used to test the normality of data as Blunch (2013) recommends. All variables were slightly positively skewed with few negatively kurtotic ones but generally, histograms and Q-Q Plots did not show any major normality problems. Whereas we identified a large number of suspicious response patterns.

The first problem was straight lining. The situation, where respondent marks the same response for a high proportion of the questions (Hair et al. 2017). Analysis of standard deviations for every respondent showed 201 cases of straight lining where a maximum of two responses was different from the rest. These cases were eliminated from the consecutive analysis. In addition, the reversely coded questions were compared by measuring in between variance with normally coded ones for a particular construct. Again, obvious careless responses were eliminated from the sample.

This procedure left us with 480 applicable answers from respondents of whom were $50.4 \%$ males and 49.6\% females from all over the Czech Republic.
The grand proportion of them was from populous regions. For instance, from Prague (16\%) South Moravia (14.6\%), Central Bohemia (13.3\%) or Moravia Silesia $(9.6 \%)$ to mention just a few. Besides, slightly over a quarter of respondents were from big cities and least represented were residents from small cities up to 1,000 inhabitants (Tab. II).

Further, mean for age was 41.9 years (SD=13.7) ranging from 16 to 65 years. Overall the age variable had slightly negative kurtosis with no significant skewness.

\section{Statistical methods}

When working with advanced marketing models, the Structural Equation Modelling, or SEM for short, is the broadly accepted choice for data analysis (Steenkamp and Baumgartner, 2000). SEM is a general statistical modelling technique which uses measurement model of factor analysis and path model. The factor analysis part of the model relates the measured variables to the latent constructs, and the path model captures the structural links relating constructs to other constructs (Iacobucci, 2013). To be more specific, factor analysis is based on correlations and covariances of measured scales forming latent constructs and path analysis has its groundings in regression analysis. Consequently, factors have regression or path coefficients between them (Hox and Bechger, 1998) allowing the researcher to test the hypothesis in the final structural model. From the range of available software packages, the IBM AMOS 21 was used.

\section{RESULTS}

It is common routine to test the measurement model (indicators for constructs) before the structural model (theory testing). Therefore, in the first part of the result section, we present reliability and validity of measurement model. This helps to determine whether the measures have satisfactory psychometric properties (Fornell and Larcker, 1981) and the chosen indicators for a construct are reliable and valid (Anderson and Gerbing, 1988).

There is a report of internal consistency (Cronbach's alfa, coposite reliability) and convergent validity (avarage variance extracted) in the Tab. III. Cronbach's alfa should be at least 0.7 (Nunnally and Bernstein, 1994), composite reliability values between 0.7 and 0.9 can be regarded as satisfactory and avarage variance extracted levels higher than

II: Sample distribution by city size

\begin{tabular}{ccc}
\hline Inhabitant & Count & Percent \\
\hline Up to 1,000 & 76 & 15.8 \\
$1,001-5,000$ & 97 & 20.2 \\
$5,001-20,000$ & 97 & 20.2 \\
$20,001-100,000$ & 87 & 18.1 \\
More than 100,001 & 123 & 25.6 \\
\hline
\end{tabular}

Source: own survey 
0.5 are recomended (Hair et al. 2017). In general, we can assume the measurement model met the basic criteria except in one case where there is a small deviation from the standards. Consequently, the Attitude towards buying grocery online have been treated with caution in further analysis.

Next, we tested our hypothesis by the means of regression (Tab. IV). Statistical significance was measured on the level of 0.001. Apparently, only two theoretized relationships were significant. Followed not only statistical assumptions which would guide us to modify the model by discarting $\mathrm{BI}$, we considered the importance of Intention variable on real customer choice and eliminate ATT instead. This latent variable had already some Avarage variance measurement issues, therefore statistically as well as empirically it was the obvious candidate for elimitation.
Originally, the Attitude and Perceived usefulness were intended to be mediators (Fig. 2). In the end, however, it turned out that PU has a possible statistical significance as a link between PEOU and BI. It was completely pointless to proceed with the calculation of the model fit before its modification.

Since the PEOU had a positive effect only on PU, we retained third hypothesis as well as the first one, which indicates a relationship between PU and endogenous variable BI and established modified model (Fig. 3). Mediating effect in the original model were replaced by simple path model.

After modification, the model was constructer in AMOS again, recalculated and both hypotheses were accepted (Tab. V). The suggested model, therefore, employs exogenous construct PEOU,

III: Reliability and validity check

\begin{tabular}{lcccc}
\hline & \multicolumn{5}{c}{ Construct } \\
\hline Measure & PU & PEOU & ATT & BI \\
\hline Cronbach's alfa & .835 & .805 & .750 & .875 \\
Composite reliability & .838 & .805 & .736 & .877 \\
Average variance extracted & .633 & .580 & .493 & .704 \\
\hline
\end{tabular}

Source: own calculation

IV: Hypotheses testing by regression

\begin{tabular}{ccc}
\hline Hypotheses & Stand. Estimate & P-Value \\
\hline H1: PU $->$ BI & -0.301 & 0.507 \\
H2: PEOU -> BI & -0.332 & 0.060 \\
H3: PEOU -> PU & 0.796 & $* * *$ \\
H4: PU $->$ ATT & 0.745 & $* * *$ \\
H5: PEOU -> ATT & 0.249 & 0,002 \\
H6: ATT $\rightarrow$ BI & 1.517 & 0.009 \\
\hline
\end{tabular}

Source: own calculation

$* * *$ P-value $<0.001$

V: Hypotheses testing in modified model

\begin{tabular}{ccc}
\hline Hypotheses & Stand. Estimate & P-Value \\
\hline Hl:PU $->$ BI & 0.868 & $* * *$ \\
H3:PEOU $->$ PU & 0.801 & $* * *$ \\
\hline
\end{tabular}

Source: own calculation

$* * * \mathrm{P}$-value $<0.001$

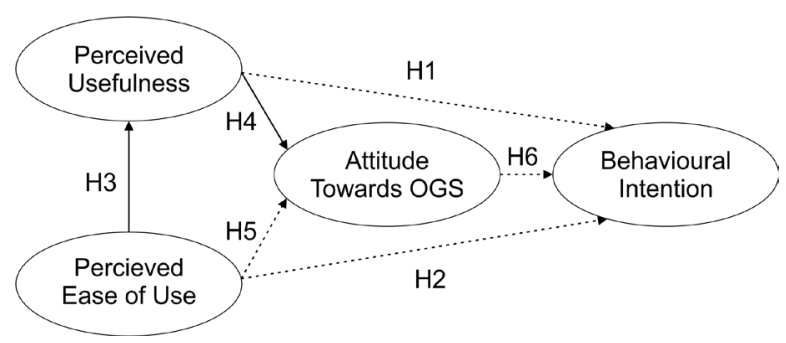

2: Structural model results Source: own elaboration 
both exogenous and endogenous construct PU and finally endogenous latent variable BI.

With the new model, study proceeded to determine the overall model fit. It was estimated using standard measurement indices recommended by SEM handbooks (Hair et al. 2017; Schumacker and Lomax, 2016; Kline, 2015). Specifically, it was the normal chi-square $\left(\chi^{2} / \mathrm{df}\right)$, the Goodness of Fit Index (GFI), the Adjusted Goodness of Fit Index (AGFI), the Root Mean Square Error of Approximation (RMSEA), the Comparative Fit Index (CFI) and Tucker-Lewis Index (TLI). These were based on indices generated as a part of AMOS output.

Results presented excellent model fit as Tab. VI shows. All of the measured indexes reached their recommended values and, in some cases, even fairly exceeded it (CFI).

\section{Discussion, research limitations and managerial implications}

Past studies have investigated what are the antecedents of online shopping (Al-Qeisi et al., 2014; Anesbury et al., 2016). What motivates people to buy online generally (Monsuwé et al., 2004) and how technology adoption affects online shopping (Kurnia and Chien, 2003; Lim and Ting, 2014; Ingham et al., 2015). However, only a few studies used TAM framework to describe the relationship between perceived usefulness of technology (interface) for consumer everyday life, ease of use of this technology, attitude towards the technology and finally the behavioural intention.
In research, these models are quite common to see in many online shopping applications (Gefen et al., 2003; Ingham et al., 2015). We have, however, deductively implemented TAM framework to online grocery shopping intentions among Czech Republic consumers. This study shows that the TAM framework can also be used when adopting online food purchases. In alignment with Davis (1989), we have demonstrated in presented modified model the relationship between perceived usefulness (PU), perceived ease of use (PEOU), and the intention to buy food online (BI). Our findings relating to the relationship between PEOU and PU support an assumption that PEOU has a significant direct effect on PU (Davis, 1987; Venkatesh and Davis, 2000; Gefen et al., 2003; Rauniar et al., 2014). In fact, the final scheme has characteristics of simple path model with a sequence of latent constructs where PEOU has a positive effect on PU and PU consequently effects BI. Attitude as the strong direct predictor of online grocery shopping was eliminated, despite the fact that this factor was confirmed as the strong direct predictor of e-shopping acceptance (Monsuwé et al., 2004; Ingham et al., 2015; Lim and Ting, 2014).

Hair et al. (2017) explain important considerations when drawing arrows between constructs. Researcher faces a trade-off between the theoretical soundness (including all relationships supported by theory) and model parsimony (using fewer relationship). They went on to say, that latter should be of crucial concern as the most non-restrictive statement "everything is predictive of everything else" is also the most uninformative. Accordingly, in

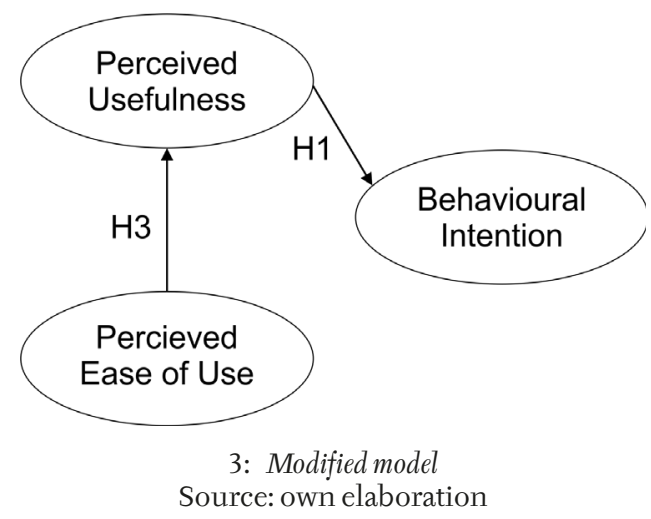

VI: Model fit

\begin{tabular}{ccc}
\hline Fit Index & $\begin{array}{c}\text { Measured } \\
\text { Level }\end{array}$ & $\begin{array}{c}\text { Recommended } \\
\text { Level }\end{array}$ \\
\hline$\chi^{2} / \mathrm{df}$ & 2.16 & $<3$ \\
GFI & .97 & $>.95$ \\
AGFI & .95 & $>.95$ \\
RMSEA & .05 & $<.07$ \\
CFI & .99 & $>.95$ \\
TLI & .98 & $>.95$ \\
\hline
\end{tabular}

Source: own calculation 
this study, the model parsimony brought very good statistical as well as empirical results.

Important theoretical implications are twofold. First, we tested the model of TAM and its suitability for measuring relationships between the constructs in OGS domain. Measurement model (single latent constructs with its observed variables) used in this research is now available to anyone who wants to follow up on this study. Second, we were forced to eliminate more than half answers from the sample because of careless responses, which is of high concern for all researchers using quantitative survey techniques.

The practical managerial implication of our results lies in the deeper understanding of consumer behaviour. We present model on which managerial decisions could be based. Perceived Ease of Use does not have a direct effect on Intention to buy, therefore the easy directions on the web page, smooth purchase process or task performance do not influence consumers solely. The publicity on the social networks can be used to improving a perception of online grocery shopping process. Describe, show and explain the entire process of purchasing grocery online together with the most important questions about ordering and delivering grocery is important attributes of the spot to positively influence consumer' perceived ease of use. Perceived Usefulness of online grocery shopping plays a crucial role in awakening the interest in buying food online. Therefore, marketers should concentrate on intensive work with people's thinking, not just with the technical setup of the online web page interface. The limitation of the development of online grocery shopping in the Czech Republic may be the underestimation of marketing communications towards the change of the consumer's mindset. Perceived Usefulness, grounded in an awareness of real value for the customer, can be increased by the encouragement of WOM of regular OGS customers (social pressure), support for trial (own experience) or intensified communication campaigns aimed (building appropriate expectations on main benefits - time, simplicity, comfort).

Almost every study in social sciences has its limitations and this one is not an exception. The data were collected form research panel where the motivation to earn money may override the interest in research study resulting in careless responses. Nevertheless, the procedure to identify these responses have been done, some of the respondents can be aware of such a procedure and undergone careless responses anyway, just by variating they answer to proceed quickly through the research. This study measured only perceptions, attitudes and intentions, not the actual behaviour. Thus, the results are not casual in nature as it would be in experimental research.

Further, SEM as a statistical technique itself has few limitations. To mention just the most important, there is a possibility that the data fits several models at once. Furthermore, we used non-experimental data, thus, the model cannot be considered casual as it is sometimes described by SEM users.

Future research on the topic of TAM in OGS could integrate external variables as predictors for Perceived Usefulness and Perceived Ease of Use as well as a specific behavioural measurement of buying behaviour which will be influenced by Behavioural Intention to buy groceries online.

\section{CONCLUSION}

Shopping of goods and services over the internet has grown dramatically over the past ten years. Many customers are for some categories of goods choosing only online shopping. One of the major categories is food or grocery shopping. Although some experts argue that selling food online is too challenging logistically and economically, the opposite seems to be true. Compared to Western Europe, food sales are not as widespread in the Czech Republic. Information about the reasons people are buying food online is crucial for managing food companies. Therefore, the aim of this paper was to explain consumer behaviour in the domain of online grocery shopping. The TAM framework was implemented on online grocery shopping intentions using structural equation modelling approach. We created a model based on a previous theory that we tested in the form of a deductive approach. For this purpose, we used quantitative methods and collected data using an online questionnaire. After initial model failed to provide sufficient statistical significance, we followed common structural equation procedure and modified the structural model to fit the data. Data were scanned for missing data, outliers, normality and suspicious response patterns. From these methods, the suspicious response patterns resulted in large sample size reduction thanks to careless responses. Despite this, there were 480 respondents in the study from all over the Czech Republic. A final proposed model which fits the data by meeting all the SEM assumptions has been developed. In fact, modifications resulted in the typical path model. The Perceived Ease of use has o positive effect on Perceived Usefulness and Perceived Usefulness consequently affects the Behavioural Intention to buy groceries online. We provide few managerial implications based on our results. Perceived Ease of Use does not have a direct effect on Intention to buy. The idea of easy directions on the web page, smooth purchase process or easy task performance online is not sufficient. Without Perceived Usefulness, the customer does not show interest in buying food online. The efforts of marketers should, therefore, focus primarily on raising awareness of the usefulness of online grocery shopping or improve the service 
to generate the appropriate value. These results can be used mainly in the area of service quality management, marketing communications and customer relationship management.

Acknowledgements

This research was financially supported by the Student grant competition project SGS/7/2017: "Acceptance of technology from the perspective of marketing tools."

\section{REFERENCES}

AJZEN I. 1989. Attitude stucture and behavior. In: PRATKANIS, A. R., BRECKLER, S. J. and GREENWALD, A. G. (Eds.). Attitude structure and function. London: Psychology Press.

AL-QEISI, K., DENNIS, C., ALAMANOS, E. and JAYAWARDHENA, C. 2014. Website design quality and usage behavior: Unified Theory of Acceptance and Use of Technology. Journal of Business Research, 67(11): 2282-2290.

ANDERSON, J. C. and GERBING, D. W. 1988. Structural equation modelling in practice: A review and recommended two-step approach. Psychological Bulletin, 103(3): 411-423.

ANESBURY, Z., NENYCZ-THIEL, M., DAWES, J. and KENNEDY, R. 2016. How do shoppers behave online? An observational study of online grocery shopping. Journal of Consumer Behaviour, 3(15): 261-270.

BLUNCH, N. 2013. Introduction to Structural Equation Modeling Using IBM SPSS Statistics and Amos. $2^{\text {nd }}$ Edition. Los Angeles: Sage.

CAGLIANO, A. C., MARCO, A. D. and RAFELE, C. 2017. E-grocery supply chain management enabled by mobile tools. Business Process Management Journal, 23(1): 47-70.

ÇELIK, H.E. and YILMAZ, V.2011. Extending the Technology Acceptance Modelfor Adoption of E-Shopping by Consumers in Turkey. Journal of Electronic Commerce Research, 12(2): 152-164.

CHILDERS, T. L., CARR, C. L., PECK, J. and CARSON, S. 2001. Hedonic and utilitarian motivations for online retail shopping behavior. Journal of Retailing, 4(77): 511-535.

CZECH STATISTICAL OFFICE. 2017. Information Society in Figures Report, 2017. Czech Statistical Office. [Online]. Available at: https://www.czso.cz/csu/czso/information_society_in_figures [Accessed: 2017, December 18

DAVIS, F. 1987. User Acceptance of Information Systems: The Technology Acceptance Model (TAM). Working paper n. 529. University of Michigan, School of Business Administration. Available at: https://deepblue. lib.umich.edu/bitstream/handle/2027.42/35547/b1409190.0001.001.txt?sequence=1\&isAllowed=y [Accessed: 2017, December 18].

DAVIS, F. 1989. Perceived usefulness, perceived ease of use, and user acceptance of information technology. MIS Quarterly, 13(3): 319-339.

EUROSTAT. 2017. Internet purchases by individuals. Dataset. [Online]. Available at: http://appsso.eurostat. ec.europa.eu/nui/submitViewTableAction.do [Accessed: 2017, December 18

FORNELL, C. and LARCKER, D. F. 1981. Evaluating Structural Equation Models with Unobservable Variables and Measurement Error. Journal of Marketing Research, 18(1): 39-50.

GEFEN, D., KARAHANNA, E. and STRAUB, D. W. 2003. Trust and TAM in Online Shopping: An Integrated Model. MIS Q, 27(1): 51-90.

HAIR, J. F., BLACK, W. C., BABIN, B. J. and ANDERSON R. E. 2010. Multivariate Data Analysis. $7^{\text {th }}$ Edition. London: Pearson Education.

HAIR, J., HULT, G. T. M., RINGLE, C. M. and SARSTEDT, M. 2017. A Primer on Partial Least Squares Structural Equation Modeling. $2^{\text {nd }}$ Edition. Los Angeles: Sage.

HANSEN, T., MØLLER JENSEN, J. and STUBBE SOLGAARD, H. 2004. Predicting online grocery buying intention: a comparison of the theory of reasoned action and the theory of planned behavior. International Journal of Information Management, 24(6): 539-550.

HOX, J. J. and BECHGER, T. M. 1998. An introduction to structural equation modelling. Family Science Review, 11:354-373.

HUIJTS, N. M. A., MOLIN, E. J. E. and STEG, L. 2012. Psychological factors influencing sustainable energy technology acceptance: A review-based comprehensive framework. Renewable and Sustainable Energy Reviews, 16(1): 525-531.

IACOBUCCI, D. 2013. Marketing Models: Multivariate Statistics and Marketing Analytics. Mason: South-Western College Pub.

INGHAM, J., CADIEUX, J. and BERRADA, A. 2015. e-Shopping acceptance: A qualitative and meta-analytic review. Information $\odot$ Management, 52(1): 44-60.

KLAPILOVÁ-KRBOVÁ, P. 2016. Shopping Behaviour of Generation Y: A Comparison of Czech Republic and Slovakia. Acta Universitatis Agriculturae et Silviculturae Mendelianae Brunensis, 64(2): 617-626.

KLINE, P. 2015. A Handbook of Test Construction (Psychology Revivals): Introduction to psychometric design. New York, NY: Methuen. 
KURNIA, S. and CHIEN, A. J. 2003. The Acceptance of Online Grocery Shopping. In: proceedings of the 17th Bled eCommerce Conference, 21-23 June. Slovenia: Faculty of Organizational Sciences. University of Maribor, pp. 219-233.

LIM, W. M. and TING, D. H. 2014. Consumer Acceptance and Continuance of Online Group Buying. Journal of Computer Information Systems, 54(3): 87-96.

LIM, W.M. and TING, D.H. 2014. Consumer Acceptance and Continuance of Online Group Buying. The Journal of Computer Information Systems, 54(3): 87-96.

MALHOTRA, N. K., BIRKS, D. F. and WILLS, P. 2012. Marketing Research: An Applied Approach. $4^{\text {th }}$ Edition. Harlow: Pearson Education.

MIŠKOLCI, S. 2017. Consumer Preferences Expressed via Shopping in Alternative Food Chains. Acta Universitatis Agriculturae et Silviculturae Mendelianae Brunensis, 65(1): 311-318.

MONSUWÉ, T., BENEDICT, G. and RUYTER, D. 2004. What drives consumers to shop online? A literature review. International Journal of Service Industry Management, 15(1): 102-121.

MUNSON, J., TIROPANIS, T. and LOWE, M. 2017. Online Grocery Shopping: Identifying Change in Consumption Practices. In: Internet Science, Lecture Notes in Computer Science: proceedings of the 4th International Conference on Internet Science, 22-24 November. Greece: Springer, Cham, pp. 192-211.

NATHALIE, T. M. D. and DJELASSI, S. 2016. An integrated model of self-service technology (SST) usage in a retail context. International Journal of Retail and Distribution Management, 44(5): 540-559.

NESLIN, S. A., GREWAL, D., LEGHORN, R., SHANKAR, V., TEERLING, M. L., THOMAS, J. S. and VERHOEF, P. C. 2006. "Challenges and Opportunities in Multichannel Management," Journal of Service Research, 9(2): 95-113.

NUNNALLY, J. C. and BERNSTEIN, I. H. 1994. Psychometric theory. $3^{\text {rd }}$ Edition. New York: McGraw-Hill.

OREL, F. D. and KARA, A. 2014. Supermarket self-checkout service quality, customer satisfaction, and loyalty: Empirical evidence from an emerging market. Journal of Retailing and Consumer Services, 21(2): 118-129.

RAUNIAR, R., RAWSKI, G., YANG, J. and JOHNSON, B. 2014. Technology acceptance model (TAM) and social media usage: an empirical study on Facebook. Journal of Enterprise Information Management, 27(1): 6-30.

REINARTZ,W.,DELLAERT,B., KRAFFT,M., KUMAR, V.and VARADARAJAN, R. 2011. RetailingInnovations in a Globalizing Retail Market Environment. Journal of Retailing, Innovations in Retailing, 87(1): 53-66.

SAUNDERS, M., LEWIS, P. and THORNHILL, A. 2016. Research Methods for Business Students. $7^{\text {th }}$ Edition. Harlow: Pearson Education.

SCHREIBER, J. B., NORA, A., STAGE, F. K., BARLOW, E. A. and KING, J. 2006. Reporting Structural Equation Modeling and Confirmatory Factor Analysis Results: A Review. The Journal of Educational Research, 99(6): 323-338.

SCHUMACKER, R. E. and LOMAX, R. G. 2016. A Beginner's Guide to Structural Equation Modeling. $4^{\text {th }}$ Edition. New York, NY: Routledge.

SOUTJIS, B., COCHOY, F. and HAGBERG, J. 2017. An ethnography of Electronic Shelf Labels: The resisted digitalization of prices in contemporary supermarkets. Journal of Retailing and Consumer Services, 39(C): 296-304.

STALK, G. 1988. Time-the next source of competitive advantage. Harvard Business Review, 66: 41-51.

STATISTA. 2017. E-commerce worldwide. Statista: The Statistics Portal. [Online]. Available at: https://www. statista.com/topics/871/online-shopping [Accessed: 2017, December 18].

STEENKAMP, J.-B. E. M. and BAUMGARTNER, H. 2000. On the use of structural equation models for marketing modeling. International Journal of Research in Marketing, 17(2-3): 195-202.

THE NIELSEN COMPANY. 2015. The Future of Grocery: e-commerce, digital technology and changing shopping preferences around the world. [Online]. Available at: https://www.nielsen.com/content/dam/nielsenglobal/ vn/docs/Reports/2015/Nielsen\%20Global\%20E-Commerce\%20and\%20The\%20New\%20Retail\%20 Report\%20APRIL\%202015\%20(Digital).pdf [Accessed: 2017, December 18].

TONI, A. and MENEGHETTI, A. 2000. Traditional and innovative paths towards time-based competition. International Journal of Production Economics, 66(3): 255-268.

VENKATESH, V. and BALA, H. 2008. Technology Acceptance Model 3 and a Research Agenda on Interventions. Decision Sciences, 39(2): 273-315.

VENKATESH, V. and DAVIS, F.D. 2000. A Theoretical Extension of the Technology Acceptance Model: Four Longitudinal Field Studies. Management Science, 46(2): 186-204.

WEBER, A.N. and BADENHORST-WEISS, J.A. 2016. Time-based competition as a competitive strategy for online grocery retailers. Journal of Contemporary Management, 13(1): 433-460.

WOLF, S. 2012. E-Grocery Shopping in Germany. Saarbrücken: AV Akademikervelag GmbH\&Co. KG

Radka Bauerová: bauerova@opf.slu.cz

Martin Klepek: klepek@opf.slu.cz 